\title{
Oestrogen metabolites in urine during the menstrual cycle, pregnancy and puerperium in the Indian hanuman langur (Presbytis entellus entellus)
}

\author{
L. N. Shandilya, * L. S. Ramaswami† and N. Shandilya* \\ Reproduction Physiology Section, Department of Zoology, University of Rajasthan, \\ Jaipur-302004,India
}

\begin{abstract}
Summary. Oestrone, oestradiol-17ß and oestriol were detected in the urine of menstruating and pregnant langur monkeys. More oestrone than the other two oestrogens was excreted during the cycle and oestradiol-17ß and oestriol could not be detected during the luteal phase. There was an increase in the amount of all the three oestrogens excreted during pregnancy when compared with the menstruating animals and oestriol was the major oestrogen excreted in the urine of pregnant langurs. Normal cyclic levels were reached 2 days after parturition. Most of the oestrogens $(95 \%)$ were conjugated with glucuronic acid and little with sulphuric acid or in any other form.
\end{abstract}

\section{Introduction}

The hormonal regulation of the menstrual cycle and pregnancy has been extensively studied in women and rhesus monkeys but information regarding other non-human primates is fragmentary.

David \& Ramaswami (1969) have studied langur monkeys in the laboratory and shown that the cycle length is $21-26$ days (mode $22 ; 68 \%$ of cycles), with ovulation occurring on Day 9 . Gestation lasts for about 170 days and usually only 1 , but sometimes 2 , young are born.

Since the reproductive tract of langurs resembles the human tract more closely than that of the rhesus monkey (David \& Ramaswami, 1971), it seemed of interest to study oestrogen excretion during the menstrual cycle, pregnancy and after parturition in langurs for a better understanding of the hormonal metabolism in these animals.

\section{Materials and Methods}

Two menstruating and four pregnant (1 week before term) langur monkeys (Presbytis entellus entellus) were used. They were housed in metabolism cages and 24-hr urine specimens were collected from Day 1 of the menstrual cycle until the onset of the next menstruation, during the last week of pregnancy and for 5 days after parturition. No preservatives were added and the urine samples, after measurement and dilution with distilled water, were stored at $-17^{\circ} \mathrm{C}$ until they were required for analysis.

Oestrogens were determined by the methods of Liskowski, Wolf, Chandler \& Meyer (1970) with certain modifications, and of Brown (1955). Three aliquots of urine were taken. The first two were for enzymatic hydrolysis, one with $\beta$-glucuronidase (Menini \& Norymberski, 1965) and the other

* Present address: Reproductive Physiology Department, C. S. Mott Center, 275, East Hancock, Detroit, Michigan 48201, U.S.A.

$\dagger$ Present address: Primate Project Director (ICMR), Institute for Research in Reproduction, J. Merwanji Street, Parel, Bombay-12, India. 
with Helix pomatia enzyme preparation containing both $\beta$-glucuronidase and sulphatase (de La Torre, Johannisson \& Diczfalusy, 1970). This method was only followed with urine samples from pregnant monkeys. The third aliquot was hydrolysed with $\mathrm{HCl}$ (Brown, 1955). Urine samples ( $100 \mathrm{ml}$ and $50 \mathrm{ml}$ for non-pregnant and pregnant langurs, respectively) were adjusted to $\mathrm{pH} 5$ with $\mathrm{HCl}$ and incubated with enzyme for $24 \mathrm{hr}$ at $38^{\circ} \mathrm{C}$ (Menini \& Norymberski, 1965). Each sample was extracted three times with $75 \mathrm{ml}$ ether. The extracts were pooled and washed with a concentrated $\mathrm{NaHCO}_{3}$ solution, and then with distilled water. The ether extract was evaporated to dryness at reduced pressure. The dry residue was dissolved in toluene $(50 \mathrm{ml})$ and the solution extracted with $1 \mathrm{~N}-\mathrm{NaOH}(3 \times 20 \mathrm{ml})$. The aqueous layer was neutralized with $\mathrm{HCl}$ and the oestrogens extracted with ether $(3 \times 60 \mathrm{ml})$. This extract was washed with distilled water and evaporated at reduced pressure. Ethanol $(10 \mathrm{ml})$ was added and then evaporated to remove any traces of water. The dry extracts were dissolved in ethanol, transferred to conical tubes and evaporated under nitrogen at $56^{\circ} \mathrm{C}$.

Urine samples, known amounts of standards of oestrone, oestradiol-17 $\beta$ and oestriol in distilled water, water blanks and urine samples to which known amounts of oestrogens were added were treated in a similar manner throughout the procedure.

After hydrolysis the urinary extracts were subjected to thin-layer chromatography using chloroform: acetone $(90: 10 \mathrm{v} / \mathrm{v}$ ) (Liskowski et al., 1970), or $7 \%$ ethanol in isopropyl ether or $20 \%$ acetone in isopropyl ether (Touchstone, Murawec \& Brual, 1968) as solvents. The oestrogens were identified by the procedures described by Waldi (1965).

For the quantitative determinations of the individual oestrogens, the urinary extracts were separated by column chromatography on Sephadex LH-20 by the method of Mikhail, Wu, Ferin \& Vande Wiele (1970). The final Kober colour was developed according to the method of Brown (1955) and the extinctions were read on a Beckman Spectrophotometer DU 2 at the wavelengths recommended by Nocke (1961). The optical density readings were corrected by applying Allen's formula (1950).
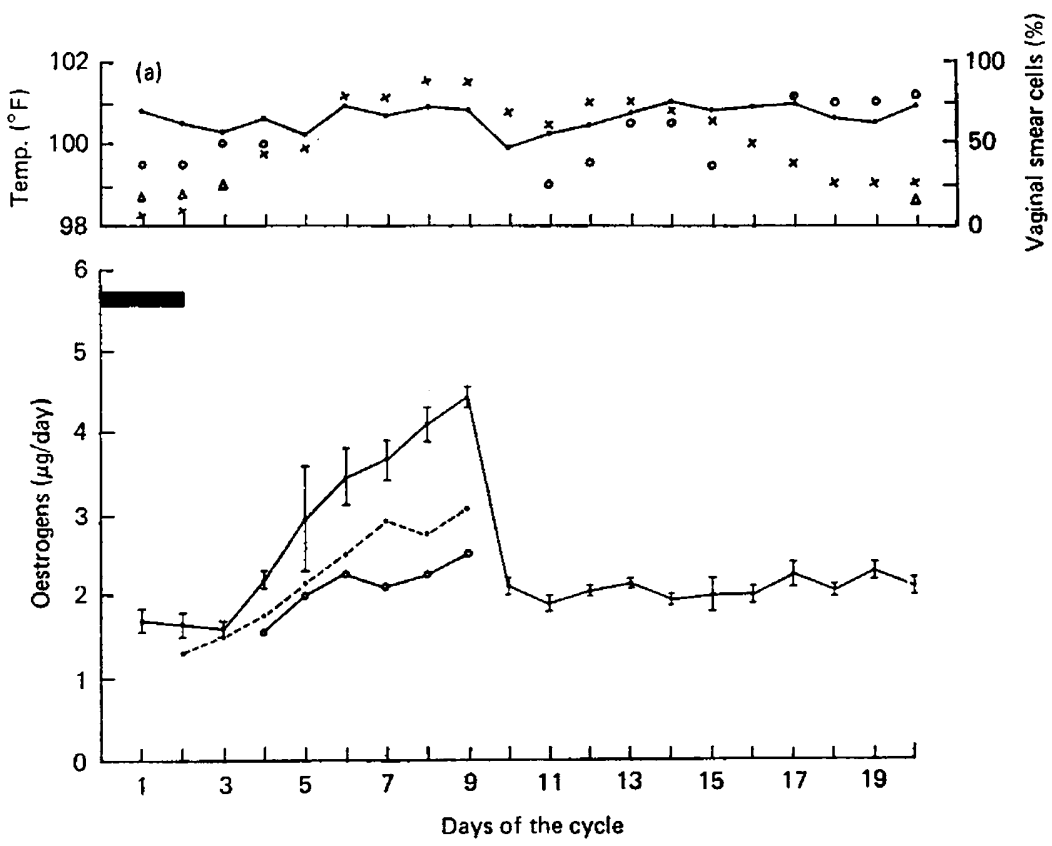

Text-fig. 1. The urinary excretion of oestrogens (b) and the temperature and vaginal cornification changes (a) of two langurs during the menstrual cycle. (a) $\triangle$, Nucleated epithelial cells; $O$, leucocytes; $x$, cornified cells; ๑, temperature. (b) —, oestrone (means \pm S.E.M., 2 cycles); ----, oestriol (mean values for 2 cycles); $\bigcirc$, oestradiol- $17 \beta$ (mean values for 2 cycles). The horizontal bar represents the time of menstruation. 


\section{Results}

Oestrogens were detected in the urine of menstruating and pregnant langur monkeys. The chromatograms of all samples showed four spots of which three repeated the mobilities and colour characteristics of authentic oestrone, oestradiol-17 $\beta$ and oestriol. The fourth spot could not be identified for want of a reference standard, but its mobility indicated that it might have been 2-methoxyoestriol. With the chloroform: acetone solvent the $R_{F}$ values were: oestrone, 0.60 ; oestradiol-17 $\beta, 0.31$; oestriol, 0.07 ; and the unidentified substance, $0 \cdot 15$. When the solvent was $7 \%$ ethanol in isopropyl ether, the $R_{F}$ values were: oestrone, 0.53 ; oestradiol-17 $\beta, 0.50$; oestriol, 0.13 ; and the unidentified substance, 0.60 . A similar movement of oestriol was found with $20 \%$ acetone in isopropyl ether as the solvent.

During the menstrual cycle (Text-fig. 1), more oestrone was excreted than oestradiol-17 $\beta$ or oestriol. The amounts of oestradiol-17 $\beta$ and oestriol excreted during the luteal phase of the cycle were below the limits of our assay. The minimal sensitivity for estimation of the oestrogens in urine varied from animal to animal, but was about $1.5 \mu \mathrm{g} /$ day for oestrone, $1.5 \mu \mathrm{g} /$ day for oestradiol and $1.0 \mu \mathrm{g} /$ day for oestriol.

Maximum oestrogen excretion occurred on the 9th day of the cycle, when vaginal cornification was also maximal. Ovulation probably occurred on Day 9 , since on Day 10 pregnanediol, detected by thin-layer chromatography, appeared in the urine and there was a drop in the vaginal temperature.

The change in oestrone levels from just after menstruation to the peak levels on Day 9 was significant $(P<0.01)$. Oestradiol-17 $\beta$ and oestriol values also increased.

Table 1. Mean ( \pm S.E.M.) oestrogen excretion $(\mu \mathrm{g} / 24 \mathrm{hr}$, uncorrected for losses) in menstruating and pregnant langur monkeys

\begin{tabular}{lccccc}
\hline \multicolumn{1}{c}{ Reproductive state } & $\begin{array}{c}\text { No. of } \\
\text { animals }\end{array}$ & $\begin{array}{c}\text { No. of } \\
\text { observations }\end{array}$ & Oestrone & $\begin{array}{c}\text { Oestradiol- } \\
17 \beta\end{array}$ & Oestriol \\
\hline $\begin{array}{l}\text { Menstruation } \\
\quad \text { Proliferative phase }\end{array}$ & 2 & 18 & $2 \cdot 86 \pm 0.37$ & $2 \cdot 10 \pm 0 \cdot 11$ & $1 \cdot 98 \pm 0.22$ \\
$\quad \begin{array}{l}\text { Luteal phase } \\
\text { Pregnancy } \\
\quad \text { Partition system of Brown (1955) for } \\
\quad \text { separating oestriol }\end{array}$ & 2 & 22 & $2 \cdot 07 \pm 0.03$ & N.D. & N.D. \\
$\quad \begin{array}{l}\text { Separation of the three oestrogens by } \\
\quad \text { Sephadex column chromatography }\end{array}$ & 4 & 28 & $24 \cdot 5 \pm 1 \cdot 58$ & $5 \cdot 37 \pm 0.64$ & $150.62 \pm 1.97$ \\
\hline
\end{tabular}

N.D. = not detectable.

Oestriol was the major oestrogen excreted in the urine of pregnant langurs (Table 1), but levels of all three oestrogens were greater (oestrone, $\times 8.8$; oestradiol-17 $\beta, \times 2.7$; oestriol, $\times 68.5$ ) than in menstruating animals. After parturition, the levels of oestrogen started to decline and by 2 days after parturition they had reached normal levels.

Table 2. Analyses (four) of the urinary oestrogens (expressed in $\mu \mathrm{g} /$ day and uncorrected for loss) of pregnant langur monkeys by different methods of hydrolysis

\begin{tabular}{|c|c|c|c|c|}
\hline Animal & Oestrogen & $\begin{array}{l}\text { After acid } \\
\text { hydrolysis }\end{array}$ & $\begin{array}{l}\text { After hydrolysis } \\
\text { with } \beta \text {-glucuroni- } \\
\text { dase }\end{array}$ & $\begin{array}{l}\text { After hydrolysis } \\
\text { with Helix } \\
\text { pomatia enzyme }\end{array}$ \\
\hline \multirow[t]{3}{*}{1} & Oestrone & $28 \cdot 20$ & $20.90(95 \%)$ & $22 \cdot 2$ \\
\hline & Oestradiol-17 $\beta$ & $7 \cdot 24$ & $5.04(90 \%)$ & $5 \cdot 61$ \\
\hline & Oestriol & $155 \cdot 20$ & $141.48(96 \%)$ & $147 \cdot 38$ \\
\hline \multirow[t]{3}{*}{2} & Oestrone & $25 \cdot 40$ & $19.27(94 \%)$ & $20 \cdot 5$ \\
\hline & Oestradiol-17 $\beta$ & $5 \cdot 10$ & $4 \cdot 15(85 \%)$ & $4 \cdot 89$ \\
\hline & Oestriol & $152 \cdot 26$ & $144.65(97 \%)$ & $149 \cdot 13$ \\
\hline \multirow[t]{3}{*}{3} & Oestrone & $23 \cdot 80$ & $18.37(95 \%)$ & $19 \cdot 34$ \\
\hline & Oestradiol-17 $\beta$ & $4 \cdot 85$ & $2.62(88 \%)$ & 2.98 \\
\hline & Oestriol & $148 \cdot 85$ & $144.83(95 \%)$ & 152.46 \\
\hline
\end{tabular}


The oestrogens were mostly conjugated with glucuronic acid $(95 \%)$ and little with sulphuric acid or in any other form (Table 2), and no free oestrogens were present in unhydrolysed urine samples. The final recoveries (mean \pm S.E.M.) with acid hydrolysis were: oestrone, $80 \pm 6 \cdot 1 \%$, oestradiol- $17 \beta$, $83 \pm 2 \cdot 9 \%$ and oestriol, $86 \pm 3 \cdot 5 \%$.

Oestriol was confirmed to be the major oestrogen excreted near term by applying the separation methods described by Touchstone et al. (1968).

\section{Discussion}

The above findings indicate that the langur, like women (Short \& Eckstein, 1961), rhesus monkeys (Dorfman \& van Wagenen, 1941; Short \& Eckstein, 1961; Laumas, 1965; Hopper \& Tullner, 1967; Liskowski et al., 1970), baboons (Merkatz \& Beling, 1969; Townsley \& Kling, 1970), chimpanzees (Allen, Diddle \& Elder, 1935; McArthur \& Fitzgerald, 1970) and gorillas (Hopper, Tullner \& Gray, 1968), excretes oestrone, oestradiol-17 $\beta$ and oestriol during the menstrual cycle and pregnancy, and that the oestrogen levels are higher during pregnancy.

Our observations on the langur are dissimilar to those reported by Laumas (1965) for rhesus monkeys in which oestriol was the major oestrogen excreted in non-pregnant animals. Our finding that oestrone was the major oestrogen during the proliferative phase of the cycle in the langur is in agreement with the report by Graham, Collins, Robinson \& Preedy (1972) in chimpanzee. The lack of a definite luteal peak of oestrogen excretion in the langur is similar to the finding of Stevens, Sparkes \& Powell (1970) in the baboon. The langur therefore resembles women, chimpanzees and gorillas in pregnancy and differs from rhesus monkeys and baboons.

The degree of conjugation (95\%) of the oestrogens studied with $\beta$-glucuronic acid was similar to the situation in pregnant women and rhesus monkeys (Beling, 1963; Hopper \& Tullner, 1967; Liskowski et al., 1970). The fact that oestriol is the major urinary metabolite in the pregnant langur, as it is in women, is compatible with the concept that the oestriol is of fetal origin (Diczfalusy, 1964).

It is apparent that the pattern of oestrogen excretion during pregnancy in the langur closely resembles that in women, though the actual quantity of oestriol excreted is much less. This study suggests, however, that the langur may be a suitable prospective model for the study of oestrogen synthesis during pregnancy.

This work was supported in part by a grant to L.S.R. from the Ford Foundation and I.C.M.R. New Delhi.

\section{References}

Allen, E., Diddle, A.W. \& Elder, J.H. (1935) Theelin content of pregnancy urine and placenta of the chimpanzee. Am. J. Physiol. 110, 593-596.

ALLEN, W.M. (1950) A simple method for analysing complicated absorption curves, of use in the colorimetric determination of urinary steroids. J. clin. Endocr. Metab. 10, 71-83.

BeLING, C.G. (1963) Gel filtration of conjugated urinary oestrogens and its application in clinical assays. Acta endocr., Copenh., Suppl. 79, 9-98.

Brown, J.B. (1955) A chemical method for the determination of oestriol, oestrone and oestradiol in human urine. Biochem. J. 60, 185-193.

David, G.F.X. \& Ramaswami, L.S. (1969) Studies on the menstrual cycle and other related phenomena in the langur (Presbytis entellus entellus Duf.). Folia primat. 11, 300-316.

David, G.F.X. \& Ramaswami, L.S. (1971) Reproductive systems of the North Indian Langur (Presbytis entellus entellus Dufresne). J. Morph. 135, 99-130.

de la Torre, B., Johannisson, E. \& Diczfalusy, E. (1970) A simple and rapid clinical method for the serial estimation of oestriol in pregnancy urine. Acta obstet. gynec. scand. 49, 165-170.

DiczFalusy, E. (1964) Endocrine functions of the human fetoplacental unit. Fedn Proc. Fedn Am. Socs exp. Biol. 23, 791-798.

Dorfman, R.I. \& van Wagenen, G. (1941) The sex hormone excretion of adult female and pregnant monkeys. Surg. Gynec. Obstet. 73, 545-548.

Graham, C.E., Collins, D.C., Robinson, H. \& Preedy, J.R.K. (1972) Urinary levels of oestrogens and pregnanediol and plasma levels of progesterone during the menstrual cycle of the chimpanzee: relationship to the sexual swelling. Endocrinology 91, 13-24. 
Hopper, B.R. \& TUlLner, W.W. (1967) Urinary estrogen excretion patterns in pregnant rhesus monkeys. Steroids 9, 517-527.

Hopper, B.R., Tullner, W.W. \& GRAY, C.W. (1968) Urinary estrogen excretion during pregnancy in a gorilla (Gorilla gorilla). Proc. Soc. exp. Biol. Med. 129, 213-214.

LaUmas, K.R. (1965) Urinary excretion of oestrogens in rhesus monkeys. J. Endocr. 31, 297-298.

Liskowski, L., Wolf, R.C., Chandler, S. \& Meyer, R.K. (1970) Urinary estrogen excretion in pregnant rhesus monkeys. Biol. Reprod. 3, 55-60.

McArthur, J.W. \& Fitzgerald, X. (1970) Cited by Graham, C.E. In The Chimpanzee, Vol. III, p. 208. Ed. G. H. Bourne. Karger, Basel.

Menini, E. \& NorymbersKi, J.K. (1965) An approach to the systematic analysis of urinary steroids. Biochem. J. 95, 1-16.

Merkatz, I.R. \& Beling, C.G. (1969) Urinary excretion of oestrogens and pregnanediol in pregnant baboon. J. Reprod. Fert., Suppl. 6, 129-135.

Mikhail, G., Wu, C.H., Ferin, M. \& Vande Wiele, R.L. (1970) Radio-immunoassay of estrone and estradiol. Acta endocr., Copenh., Suppl. 147, 347-366. NoCKE, W. (1961) A study of the colorimetric estimation of oestradiol-17 $\beta$, oestradiol-17 $\alpha$, oestrone, oestriol and 16-epioestriol by the Kober reaction. Biochem.J. 78, 593-602.

ShORT, R.V. \& EcksteIN, P. (1961) Oestrogen and progesterone levels in pregnant rhesus monkeys. $J$. Endocr. 22, 15-22.

Stevens, V.C., Sparks, S.J. \& Powell, J.E. (1970) Levels of estrogens, progestogens and luteinizing hormone during the menstrual cycle of the baboon. Endocrinology 87, 658-666.

Townsley, J.C. \& KLING, O.R. (1970) Oestrogen synthesis by pregnant baboon: the contribution of maternal circulating precursors to urinary oestrogens. Biochem. J. 120, 23P.

Touchstone, J.C., Murawec, T. \& Brual, O. (1968) Improved solvent systems for thin layer chromatography of estrogens. $J$. Chromatog. 37, 359360.

Waldi, D. (1965) Steroids. In Thin Layer Chromatography. A Laboratory Handbook, pp. 178, 179, 249-272. Ed. E. Stahl. Academic Press, London.

Received 22 May 1975 